\title{
DISCURSIVE DEPICTION OF CUSTOMARY CONFLICT MANAGEMENT PRINCIPLES IN SELECTED AFRICAN PROVERBS
}

\author{
Mehari Yimulaw Gebregeorgis
}

\begin{abstract}
The objective of this study is to explore how proverbs of traditional African societies contribute to depicting the communities' conflict prevention and conflict management principles. To this end, proverbs collected from different parts of Africa, mainly Nigeria, Ghana, Cameroon, Republic of Congo, Botswana, Zimbabwe, Kenya, and Ethiopia were analysed using socio-semiotic approach to discourse studies and interpretive analysis. The findings of the study show that the proverbs of traditional African societies are instrumental in depicting the societies' conflict prevention and conflict management principles. Together with the 'prevention is better than cure' doctrine, taking communal responsibility, transparent truth-finding, participatory negotiation, win-win solution, and reconciliation and restoration of social harmony are among the traditional African conflict management principles that are portrayed through different African communities' proverbs.
\end{abstract}

Keywords: conflict, prevention, proverb, reconciliation, societies

\section{INTRODUCTION}

Conflict, which goes back to the origin of human beings, is "a relationship between two or more parties who have or think that they have, incompatible goals" (GIZ 2013: 13). It is exhibited at national, communal, and familial levels. Societies, groups, and individuals enter into disputes to control scarce resources such as power, money, and land. As long as individuals, groups, and societies continue to have socially structured clashes of interests and values, conflict remains part and parcel of human life. To illustrate this fact, the Ethiopians say: "Even the legs of one person get the friction of a quarrel" (Gira ena qegn egirm ygachalu) (ibid.: 19).

Despite its being an experience common to all races, there can be differences in the forms and levels of conflict in societies and in answer to them they have developed their respective conflict resolution mechanisms. The mechanisms can be formal or/and informal justice systems. Because they are culturally ap- 
propriate, economically affordable, and bureaucratically swift, informal justice systems "are the cornerstone of dispute resolution and access to justice for the majority of populations, especially the poor and disadvantaged in many countries, where informal justice systems usually resolve between 80 and 90 per cent of disputes" (Wojkowska 2006: 5-6). Aware of these merits, in 2004 the then UN Secretary General, Kofi Annan, indicated in his report to the Security Council that "due regard must be given to indigenous and informal traditions for administering justice or settling disputes, to help them continue their often vital role and to do so in conformity with both international standards and local tradition" (UN 2004: 12).

Customary conflict resolution mechanisms are not only methodically bound up with the social and economic realities of everyday life in traditional African societies, but are also strongly rooted in the culture and history of the people of the continent. Hence, "large segments of the rural populations, the overwhelming majority in most African countries, continue to adhere principally to traditional institutions" (ECA 2007: 1). In traditional African societies, rules in customary conflict resolution institutions are more dependable, better able to deal with conflict and accepted as legitimate. As a result, communities are more obedient to the customary rules (Nkonya \& Markelova \& Kato 2009). As much as they can, traditional African societies try to avoid having recourse to westernised justice systems. For example, the Yoruba of south-western Nigeria always pray: "Whether for good or bad may God not let us have a court case" (Atebi atare Olorun ma je a rejo) (Albert et al. 1995: 15). Aware of this, Kuruk states that "in no African country is customary law totally disregarded, or proscribed" (Kuruk 2002: 13).

Traditional African conflict resolution philosophies handed down from generation to generation have been a source of guidance on maintaining the peace and harmony of communities. As oral societies, traditional Africans have used folklore such as tales, idioms, riddles and proverbs to deliver their views on conflicts and their resolution mechanisms. These genres are instrumental in conveying what to do and what not to do for harmonious coexistence. From familial to communal levels, folklore is "mostly used to praise, to scold or appraise people's behaviour, hence promote or rather coerce accepted good morals among the people. The idioms, riddles and proverbs encourage people to adhere and strive for good societal moral values which in a way help them to be tolerant towards each other" (Moumakwa 2010: 42).

In doing so, proverbs, one genre of communicating traditional communities' conflict prevention and conflict management knowledge, are fused in discourse where and when appropriate as they are not learned and used separately (Yankah 2012). 
Proverbs can be studied from different perspectives as they have both areas of improvement and areas of strength. Different communities have proverbs which help to resolve conflict; equally, they have proverbs which portray prejudices on different sections of a society. For example, see Hussein (2009) and Yitah (2006) for gender stereotyping role of sexist proverbs in East and West Africa respectively. The scope of this study was, however, limited to the contributions of proverbs in resolving conflict. Specifically, the objective of the study was to explore how traditional African conflict prevention and conflict management principles are depicted in African proverbs.

Following the introduction, the conceptual framework of the study is discussed and the methodology is then presented. Based on the methodology, traditional African conflict prevention and conflict management principles depicted in their proverbs are analysed. Finally, concluding remarks are given.

\section{CONCEPTUAL FRAMEWORK}

A proverb is a medium that conveys numerous superior and compact ideas and beliefs. Although all societies use proverbs as a means of portraying their knowledge and life philosophies, their role for illiterate society in this regard is irreplaceable. "Proverbs have been used as disseminators of traditional wisdom, knowledge and apparent truths that are handed down from generation to generation, especially in the absence of vigorous written literature" (Degnew \& Wodajo 2014: 94). Though proverbs talk about human beings, like other folklores, they are metaphorical narratives based on animals, plants, people etc. Rich vocabulary, graphic statement, allusions, association and comparison are the main language features of proverbs (Adeyemi \& Salawudeen 2014).

Finnegan (1970: 390) says that "in many African cultures a feeling for language, for imagery, and for the expression of abstract ideas through compressed and allusive phraseology comes out particularly in proverbs". Similarly, Adegoju (2009: 58) opines that proverbs are employed to "communicate truths that may be abstract and difficult to grasp, as they usually dramatize and configure the bare truths in the facts of everyday life. Through this, such truths become so substantial that they stimulate imagination and challenge our understanding of situations". As a result, proverbs enhance the pragmatic effect of the speaker's communicative intent, clarity, and taste. The Ethiopians say, "As tej (Ethiopian local beer made of honey and hops) is drunk using brelee (a round vase-shaped container made of glass), a matter is discussed using proverbs"1 (Neger bemsale tej be bril). The analogy here is between breele, the container, and proverb, the medium. As brelee is the appropriate container for drinking the local beer, 
proverbs are a suitable medium for discussing issues. Otherwise, as the Oromo of the same country say, "A speech without a proverb is like a stew without salt" (Dubbiin mammaaksa hin qabne ittoo sooqidda hin qabne) (Hussein 2009: 97). Here, the analogy is between salt and a proverb. As a stew is made delicious by adding salt, conversation is made interesting by employing proverbs. In this regard, the Nigerians explicitly say, "Proverbs constitute the spice or salt of human communication" (nnu e ji eri okwu) (Oraegbunam 2009: 58).

As a repository of traditional African knowledge, philosophy, customs, ethical standards, morals, and wisdom, proverbs have a vital educational function. "Proverbs are central to indigenous education and various themes of traditional education were imparted through the vehicle of proverbs" (Adeyemi \& Salawudeen 2014: 188). They instigate reflection and invite deeper thinking and consideration of issues. They help to shape the sentiments, views, and moral awareness of one's audience. Aware of these benefits, traditional leaders and mediators ${ }^{2}$ use proverbs to exert a strong moral force and correct social wrongs. As Olatunji clearly states, the use of proverbs to teach socialisation and deterrence is prescriptive. They "outline a rule of conduct. They state what should or should not be done and lay conditions for certain actions and attitudes. They serve as social charters condemning some practices while recommending others" (Olatunji 1984: 175).

As a part of the indigenous knowledge systems entrenched in the cultural practices of communities and communal wisdom, intellectualism and morality in conflict prevention and conflict management are often conveyed through proverbs. Properly used, conflict prevention and conflict management proverbs are tough to refute; instead, they make people think critically about their view of the matter. In this way, proverbs serve as a "law that regulates societal codes of conduct. This makes them not only persuasive but useful in preventing conflict from happening and stopping conflict once it would have broken up" (Makamani 2013: 8). In conflict prevention and resolution, African proverbs are instrumental in providing speakers with a medium through which to realise a variety of communally anticipated goals. They are used as tools to persuade when settling disputes; teach communal morals; expound lessons of good and evil; give guidance on right actions and explain the need for and benefits of mutual understanding and peaceful coexistence.

For example, the following authentic martial conflict resolution scenario from Urhobo community of Nigeria in Ohwovoriole (2011: 126-128) clearly depicts how discourse participants employ proverbs as salt or spice with the aim of adding the persuasive effect on their discourse. 


\section{Conflict resolution scenario 1}

Cause of conflict:

Discourse participants: financial problems of the family

- wife, trades in corn and runs a little poultry business

- husband, an assistant driver

- six mediators (four male and two female relatives)

Venue: husband's family

The dialogue was held on a family issue among the discourse participants mentioned above. The husband, who had been trained in poultry business but preferred to be a driving assistant, had given the responsibility of the poultry business to his wife. But his wife did not like the idea and she wanted her husband to come back home and run the poultry business himself. She was urging him to do so with the help of the mediators. Hereafter, the dialogue between the participants went on as follows:

1. Woman: I no longer understand what my husband is doing. You are all witnesses that he

2. only came home because of the injury that almost took his life. He has left the care of

3. the family to me. One finger cannot pick uplouse from the head. He spends his time and

4. money on mistresses that give him incurable diseases. I want to know

5. why he neglects the children and me.

6. Man: Are you now the man in this marriage?

7. Woman: I am a woman. Why should I do the work a woman should do as well as that

8. which a man ought to do? I will not run that poultry again.

9. Man:(retorts in anger) I am your husband and you must not forget that I am the one to

10. make all the decisions in this union and your duty is to obey. Have you ever asked why I

11. had to take up the assistant driver's job? A person who has one finger pointing at

12. another has three pointing towards himself.

13. 1st Mediator: My brother, the hand of the squirrel should not deny one of the

14. elephant's thigh. I do not see the sense in your neglecting your lucrative poultry

15. business and staying away from your family for the most part of the year. Husband, do this

16. so that I do that and that makes the home peaceful. I am not against you, but remember,

17. when the roots of a tree begin to decay, it spreads death to the branches.

18. 2nd Mediator: My child, your words are hard and are not expected from a sensible

19. woman like you. This is not enough for you to fight over. If a man sees a snake and a

20. woman kills it, it is all right as long as the snake is killed. The husband and the

21. children are yours. You should not use your mouth to bring them bad luck. When the 
22. earthworm pays respect to the soil, it opens for it.

23. 3rd Mediator: My people, my sister needs to be encouraged here. Taking care of five

24. children alone is not easy. One who defecates on the roadside gives room for the

25. passers-by to curse him. Six months ago the baby had chickenpox and was admitted to

26. hospital. The doctor and nurses kept asking for the child's father and he never came in

27. spite of several messages sent to him. My sister has her goods to sell in addition to

28. running the poultry. If one cannot help the wife to carry her load, one should not

29. add to the burden.

30. 4th Mediator:

My people, "This is not enough for you to fight over" makes the fighter angry.

31. When will my son learn that assistant driver's job is dangerous and unprofitable?

32. Whenever the vehicle breaks down on a long journey, you have to spend the night in it

33. instead of the comfort of your bed. The sooner you resign from this job and return, the

34. better for you and your household. I understand the poultry business is lucrative. If

35. properly managed, whatever income received from it should be enough to maintain your

36. family. A person carrying an elephant home on his head need not use his toes to dig

37. up cricket on the way. Come home and take care of your wife and your children. This

38. will please all of us here. When a child is given what she has been clamouring for, her

39. restlessness disappears. I hope I have spoken the mind of everybody here, but I want

40. him to respond.

41. Man: My elders, I thank you very much for this meeting. You need only tell a child a

42. phrase and he completes the sentence. I have heard all you have told me. I promise to

43. give up the job in another two weeks after I have collected this month's salary from the

44. company.

Using proverbs, disputants are pressed to overcome their feelings of resentment and anger, which lead to retaliation, accusations, and counter-accusations. They are urged to forgive each other and restore peace (Ohwovoriole 2011). They are further encouraged to concentrate on tolerance and mutual aid, which restore and sustain communal peace. In this regard, Akinmade (2012: 128) argues that proverbs "perform diverse functions, ranging from bringing peace where there is conflict and misunderstandings, giving hope where there is despair and light where there is darkness in human relationships and interactions". 


\section{METHODOLOGY}

A qualitative research methodology was used to explore how proverbs of traditional African societies contribute to depicting the communities' conflict prevention and conflict management principles. In the genre of qualitative research, this study specifically employed the socio-semiotic approach to discourse studies and interpretive analysis. While the latter adheres to analysis of discourse to discover what social beliefs it constructs and what social actions it performs, the former, according to Renkema (2004), advocates that social context is fundamental in the study of discourse. Halliday and Hasan (1985) argue that there are three concepts of discourse that help us interpret the social context: the field (social action in which a participant is engaged), tenor (participant in the social action), and mode (what role the language plays). In this study, conflict prevention and conflict management, disputants and mediators, and proverbial discourse as a means of conveying conflict prevention and conflict management principles are understood as the field, tenor, and mode respectively.

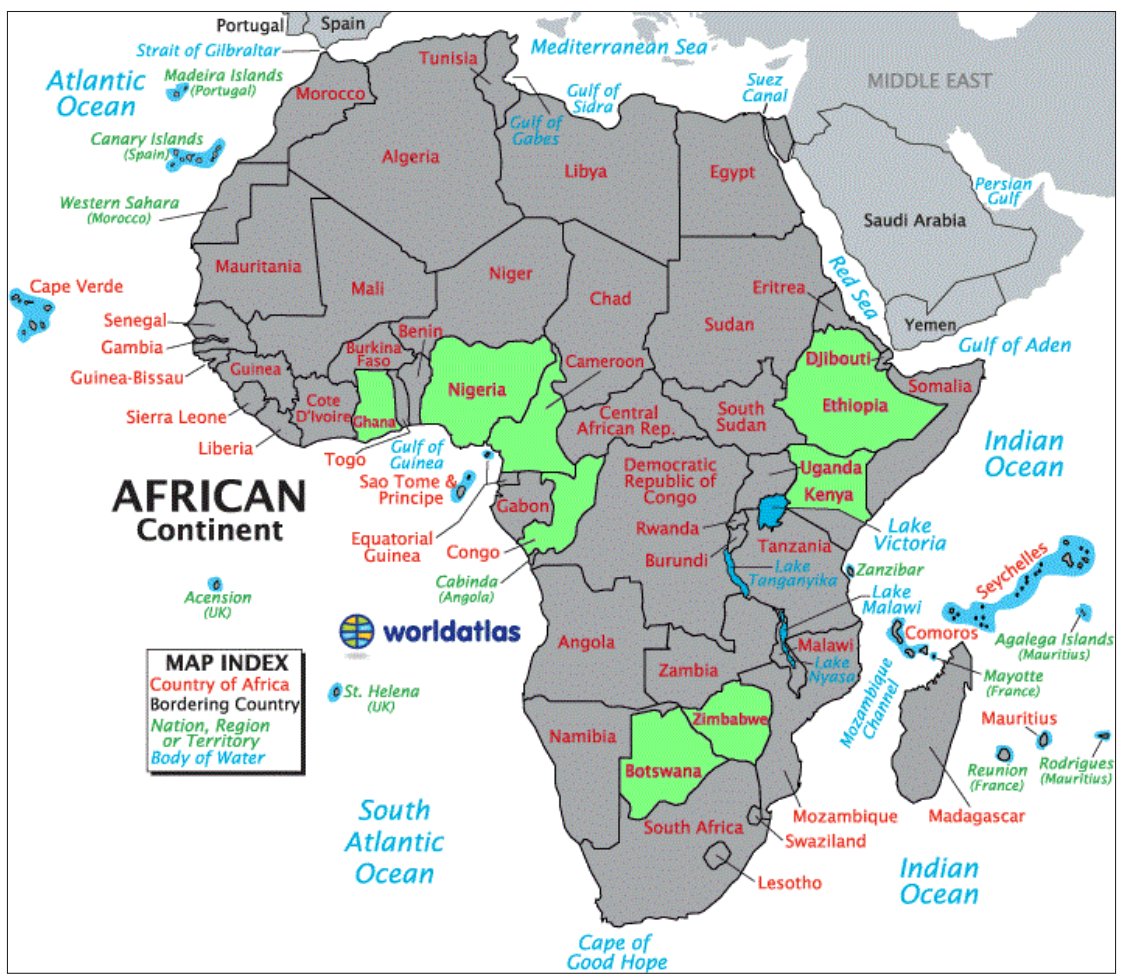

Figure 1. Locations of the main sources of data across the continent (http: / / www.worldatlas.com / webimage/countrys / africa/africaa.htm). 
Through convenience sampling, published and unpublished resources on traditional African proverbs were accessed. First, more than 400 proverbs were grossly collected mainly from: Nigeria, Ghana, Cameroon, Republic of Congo, Botswana, Zimbabwe, Kenya, and Ethiopia. Then, through purposive sampling, 110 proverbs on conflict and its prevention and management principles from all the main data source countries were selected for analysis.

In this study, language is understood as part of the major social processes and activities which construct social reality. Along with this, in the course of analysing discourse to discover what social reality and ideology it represents, discourse is defined as "the interrelated sets of texts and the practices of production, dissemination and reception that bring a particular version of social reality into being" (Porter 2005: 3); hence, the role of language in the process of constructing social beliefs about conflict and the means of preventing and managing it is drawn. In other words, traditional African discourse conveyed through proverbs on conflict prevention and conflict management was analysed to discover what social action it performs and what social reality it constructs. In this way, the study elucidates how traditional Africans use their proverbs to impart their conflict prevention and conflict management principles.

As employing proverbs requires seeing one thing in terms of another, aiming at more vividness, the analysis and interpretation were made considering the appropriateness of the context in which the proverb was used. Specifically, the relationship and fitness of the proverb to its referent in the social context were considered. In fact, the micro-analysis was made with the assumption that the multifaceted social, cultural, ideological, and societal structures which affect the proverbs' production and interpretation are the macro-context in which the proverbs exist.

Every traditional African community has its own sound conflict prevention and conflict management institution. Although they are sensitive to the sociocultural situations of the participants, most traditional African conflict prevention and conflict management mechanisms display common features. One medium for depicting these shared principles is folklore. The following section discusses how selected proverbs from different African societies portray their principles of conflict prevention and conflict management.

\section{CONFLICT PREVENTION}

Traditional African societies understand that human beings are social animals. One cannot live without the support and recognition of others. According to Kaphagawani (2006), quoted in Mandova \& Wasosa (2013: 876), their motto, 
"I am because we are, and since we are therefore I am", clearly depicts their philosophy. In line with this, Olateju further explains:

The inherently African semantic field of ubuntu provides a good example in this regard. It signifies a socially caring and sharing way of thinking and living, which is well captured in the rhyming Xhosa expression, Umntu ngumntu ngabantu [sic]. Literally this means that a human being is a human being through human beings. Or, paraphrased, a human being becomes a true human being through her/his relationships with other human beings. Similar or comparable expressions are found all over Africa. (Olateju 2013: 234)

Indeed, regardless of its different linguistic form, this principle is found in almost all traditional African societies. For example, the Tigray from Ethiopia assert that "The cure for human being is a human being" (Nisbis ya medhanit seb).

Hence, traditional African societies believe that full intention and commitment to accept and respect the humanity of the other is a precondition for peaceful coexistence. They understand and sense others' interest as the others do for them because, as the Urhobo community of Nigeria say, "When the earthworm pays respect to the soil, it opens for it" (Ohwovoriole (2011: 127) (see the conflict resolution scenario 1 , Nos. $21 \& 22$ ). In order not to spoil this healthy relationship, 'prevention is better than cure' is the fundamental principle of most of traditional African conflict prevention and conflict management institutions. For example, the Amhara say, "Take care instead of suffering the consequences" (Tamo kememaqeq askedmo metenqeq).

One source of conflict, according to traditional African societies, is opening a space for dispute. In this regard, the Yoruba from Nigeria say, "If the wall does not open up, the lizard will not be able to enter" (Bi ogiri ko la nu, Alangba ko le r'aye wo be) (Abayomi 2014: 2). In the same way, the Amhara say, "Hyena enters through a way paved by dog" (Wusha beqededew jib yigebal). Both proverbs are laden with imagery. While lizard and hyena are metaphors for something evil that causes conflict, the hole in both proverbs is a metaphor for misunderstanding between disputants. So, the lesson drawn from these proverbs is, "Do not leave space for conflict". As leaving a physical space allows lizard and hyena to enter, leaving space for misunderstanding will lead to dispute.

In order to close the space for conflict, communities need to predict potential sources of conflict. As the Africans say, it is then that they will overcome them. "You can only jump over a ditch if you have seen it from afar" (Malunga \& James 2004: 5). The ditch here symbolises a potential source of conflict. In line with this, traditional African societies understand that not being able to keep the required physical and relational distance is one source of conflicts. To 
express this social truth, the Nigerians and the Cameroonians say, "Familiarity breeds contempt; distance breeds respect", and "Do not step on the dog's tail, and he will not bite you", respectively. In the latter, a dog is a metaphor for another person. As a dog does not bite you as long as you do not touch its tail, by extension, a person does not attack you if you refrain from attacking him/her.

When there is misunderstanding, violent conflict resolution mechanisms are not advised as a solution. Instead, communities encourage solving the problem through discussion. For instance, this belief is clearly portrayed in the following proverb from Botswana: "The greatest fight is verbal" (Ntwa kgolo ke ya molomo) (Moumakwa 2010: 43). Correspondingly, the Kenyans say, "A man who uses force is afraid of reasoning". Furthermore, to succinctly indicate the relevance of being careful to maintain peaceful relationships, the same people say, "Do not say the first thing that comes to your mind". The reason for urging people to think before they speak is also clearly captured in the Yoruba proverb, "A good word may bring forth kola nut from the pocket while a bad one may bring forth the arrow from the scabbard" (Iwo ti o ka sa igi, liagbe, ti, okota ogure lofa, ti ode idi opeti ogbe enu s'oke ope nrol' asan ni) (Obisakin 2010: 55). Similarly, the Oromo of Ethiopia promote non-violent communication by saying, "Good words are better than good bedrooms" (Afaan gaariin hafaa gaarii caala) (GIZ 2013: 56).

Generally, in their effort to prevent conflict, traditional African societies are aware of the need for patience. That is why the Fulbe people who live in West, Central, and East Africa say, "Patience can cook a stone" (Munyal deefan hayre) (Afriprov 2005: 1). Here, a stone is a metaphor for a problem which in the beginning looks irresolvable. Therefore, the lesson being conveyed in this proverb is that there is no problem that cannot be solved as long as there is patience.

\section{CONFLICT MANAGEMENT}

Regardless of their effort to prevent, traditional African societies discern that conflict is part and parcel of being human. For example, the Zimbabweans say, "Committing a crime is not associated with a tree but with human beings" (Mhosva haiwiri pamuti asi pamunhu) (Mandova \& Wasosa 2013: 875). Again, the Batswana (citizens of Botswana) say, "A wrong does not decay; it is the meat that decays" (Moumakwa 2010: 59). By this, they mean that social conflict is natural. The remedy is acknowledging this social reality and addressing it peacefully whenever it happens (Phillips 2011).

Traditional African societies believe that a conflict has to be managed as soon as possible. To remind us of this, the Kenyans say, "Those who get to the 
river early drink the cleanest water". If a conflict is not managed within a short period of time, the problem will become large and complex. In this regard, the Ethiopians believe that "evil penetrates like a needle and then becomes like an oak tree". Likewise the Zimbabweans warn us that if a conflict is not resolved as soon as possible, it will be exposed to third-party interference: this is captured in their proverb, "Slowness is of the leopard; the hyena ate in transit" (Chinono chikave chengwe; Bere rakadya richifamba) (Mandova \& Wasosa 2013: 875). So, as the Yoruba say, "One dares not go to bed with the roof on fire" (A ki $i$ finá sórí òrùlé sùn) (Adegoju 2009: 63). In this regard, the Amhara say, "Put out the fire before it destroys" (Sayqatel beqtel) (GIZ 2013: 77).

Traditional African societies, however, do not like to turn to West-oriented justice systems; according to Ayittey (1991), quoted in Phillips (2011: 149), they believe that "establishing guilt and executing retribution and punishment without reference to the victim or the wider families or future reincorporation of the offender into the community" are not good for lasting peaceful coexistence of communities. The same belief is held by the Yoruba, who say, "Litigants do not return from the court and remain friends" (A kii ti kootu bo ka sore) (Phillips 2011: 149).

Traditional African societies rely on their customary conflict resolution institutions. They believe in discussion. For example, the Batswana say, "The good of the conflict is discussion" (Molemo wa kgang ke go buiwa) (Moumakwa 2010: 43). Similarly, the Kenyans understand that "having a good discussion is like having riches". Wise mediators and community leaders are responsible for settling disputes through mediation. The Yoruba people say, "One never hears 'beat him up' from the mouth of an elder" (A kii gbo "lu u" lenu agba) (Adeyemi \& Salawudeen 2014: 190). The following sub-sections discuss in more detail how traditional African communities employ proverbs in applying their conflict management principles.

\section{COMMUNAL RESPONSIBILITY AND TRANSPARENT TRUTH-FINDING}

In sociocentric traditional African communities, conflict is not seen as an individual issue. Kaphagawani (2006), quoted in Mandova and Wasosa (2013: 876), argues that most traditional African societies share the view that "whatever happens to the individual happens to the whole group, and whatever happens to the whole group happens to the individual". Be it on the side of the accused in taking responsibility for the damage or on the side of the victim in reacting to the offence, issues are handled at communal level because, according to the 
Cameroonians, "Rain does not fall on one roof alone". The message conveyed through the proverb is that the impact of an event on an individual, be it good or bad, has a certain impact on the other members of the community as well. With this understanding, the family or community is accountable for the offence committed by its member. By the same token, the family or community is expected to defend a member who is a victim (Kuruk 2002). The reason for this solidarity, according to the Ethiopians, is, "A single stick may smoke, but it will not burn". There are also different versions of the proverb from different countries. The Nigerians say, "One finger cannot pick up louse from the head" (Urhiobo ovo se muee ishuu) (Ohwovoriole 2011: 132) (see conflict resolution scenario 1 , No. 3). In the same way, to underscore how a collective response to a problem is a force which makes it possible to speak, to be listened to and eventually to solve the problem, the Congolese say, "A single bracelet does not jingle". In all the aforementioned proverbs, the single stick, one finger, and the single bracelet are metaphors for an individual member of a community. Showing the individual's inability to solve big challenges alone, traditional African communities advocate the benefits of cooperation in resolving the conflict. In this regard, the Ethiopians say, "When spider webs unite, they can tie up a lion" (Dir siyaber anbesa yasr). Here, individuals are symbolised as weak as a single spider web. The lesson in this proverb is that as the webs brought together could tie up a lion, united individuals can solve a difficult problem. Beyond safeguarding the disputants, collective responsibility is preferred to individual accountability for a smooth settlement of the dispute, as we can learn from the Swahili proverb, "Where there are many, nothing goes wrong".

When they start discussion on behalf of an offender from their group, Amhara mediators often say, "A cow gave birth to a fire: she wanted to lick it, but it burned; she wanted to leave it, but she could not because it was her own child" (Lam esat welda endatlsat aqatelat endattewat weldat). In the proverb, the lawbreaker is symbolised by a fire while his or her family or clan is represented by a cow. Mediators quote the proverb to preach the community that they should defame the wrongdoer and take collective responsibility eventually. The proverb also indicates that the family or the clan that takes the responsibility for it has no choice as long as the wrongdoer is a member of the unit. To declare the family's or the clan's willingness to take responsibility for the offence committed by their member, the same community says, "A cow's horns are not heavy for it" (Le lam kendwo aykebdatme). In the same vein, the Zimbabweans say, "An elephant's tusks are never too heavy for it". Here the offending member is symbolised by the horn of the cow / tusk of an elephant to show that as no part of the body is too heavy for the individual to carry, a clan/family member is a part of the community and cannot be a burden for the group. In traditional 
African societies, whatever mistake you make, your family or clan members are on your side to share your problem and to co-own the solution.

Once the accused side takes responsibility, mediators discover the root cause of the conflict through investigation. To this end, mediators encourage disputants to be open and honest in telling the real cause of the dispute. In doing so, the Amhara say, "Fetch water from the source; verify the matter from deep within" (Negern kesiru wuhan ketiru) (GIZ 2013: 31). Otherwise, as the Tigray from the same country say, "He who conceals his wound hides medicine for his wound" (Habaeya quslus habae medhanitu).

Mediators also use other proverbs to further urge disputants to tell the truth. For example, the Tigray say, "Truth may get thin but it won't be wrecked" (Haqis tqetin ember aytbtekn). The Batswana add, "Ninety-nine lies may help you, but the hundredth will give you away". The Cameroonians' version of this wisdom is, "Lying can get you a wife, but it won't keep her". The abovementioned proverbs say that regardless of the time it takes, the truth will be revealed eventually. As the Cameroonians say, "The darkness of night cannot stop the light of morning". Here, darkness and light are metaphors for lies and truth respectively. The Tigray warn an alleged liar that "Food carried for a certain trip, and liars, gradually get lighter" (Sinqin hashawin endahader yqell). Here, the analogy is between the gradual reduction of the weight of food consumed on a journey and the eventual untrustworthiness of a liar.

Mediators employ these proverbs to preach that unless the real cause of the problem is identified, a lasting solution cannot be found. If the peaceful dispute resolution process is to come up with a real solution, disputants have to honestly reveal the real cause of their problem. By doing so, disputants can proceed to mutual understanding and common ground, which are crucial to resolving the dispute. In this regard, the Oromo from Ethiopia say, "People can agree when they understand one another well" (Yoo waligalaan alaa galaan) (GIZ 2013: 46).

In the course of an examination, in Botswana, for example, mediators and leaders make the disputants sit in front of them so that they will have eye contact with them. Mediators do this for they believe that "words are easily spoken out when facing each other" (Mafoko a matlhong) (Moumakwa 2010: 53), and the Amhara say, "Discussants communicate well through facial expression" (Negre beayin yigebal). This strategy helps to monitor disputants' body language in order to discourage them from telling untruth. Following the establishment of truth, the conflict management process proceeds to negotiation, solution, and reconciliation. 


\section{PARTICIPATORY NEGOTIATION, WIN-WIN SOLUTION, AND RECONCILIATION}

In traditional African conflict resolution institutions, mediators or community leaders do not simply impose their decision on disputants. Instead, they allow participation by those attending the court hearing in general and the disputants in particular. The general public is invited to put forward their comments on any aspect of the process. In this regard, the Batswana say, "Everyone has a right to say what they think" (Mmualebe o a bo a bua la gagwe). Speakers are not judged for whatever they say at the trial because the same people believe that "all said at the kgotla (a customary conflict resolution institution in Botswana) is beautiful" (Mafoko a kgotla a mantle otlhe) (Moumakwa 2010: 24). The Zimbabweans' version of this wisdom says, "A court knows no fool" (Dare harina benzi) (Mandova \& Wasosa 2013: 876). The proverbs denote that everyone's contribution to the traditional court proceedings is valued and respected on the understanding that it is the individual's right to voice whatever opinion they have. These practices help traditional African communities develop a sense of owning their respective traditional conflict resolution mechanisms and strengthen their ties and accountability to these institutions' ethos.

After the victim of the conflict is soothed, the mediators set the stage for disputants to meet face to face. Based on the principle demonstrated in the African proverb, "A mother of twins must sleep on her back" (Malunga \& James 2004: 5), mediators work to embrace both the victim and the offender. They do so by encouraging both sides to be morally upright people who demonstrate good manners, helpfulness, concern, compassion, sincerity, and so on (Moumakwa 2010: 41).

Disputants are allowed to present their positions (their mutually exclusive demands), interests (the motivation underlying their demands), and needs (their requirements) (GIZ 2013: 31). In the course of negotiation, however, mediators urge disputants to adhere to non-violent discussion focusing on decreasing tension, blame, and counter-blame. In this regard, the Zimbabweans say, "A court does not condemn an individual but it condemns the crime" (Dare harizonde munhu, varume dare rinozonda mhosva) (Mandova \& Wasosa 2013: 876). They advise disputants to restrain themselves from using bad words. For example, the Yoruba people say, "It is your utterance that will determine the reply that you get" (Isoro ni igbesi) (Obisakin 2010: 44). Mediators counsel disputants to restrain themselves from pointing fingers at one another. In this regard, the Nigerians adhere to the belief that "A person who has one finger pointing at another has three pointing towards himself" (Ohwo re onie uriobo ovo ke ohwofa vwe era onie koma roye) (Ohwovoriole 2011: 127) (see conflict resolution 
scenario 1, Nos. 11-12). Likewise, the Zimbabweans say, "The monkey does not see his own backside; it sees its neighbour's". By saying so, mediators try to make the disputants look at themselves instead of pointing a finger at their opponents.

Disputants, particularly the victim of the conflict, are urged to accept the peaceful way of dispute resolution for the sake of innocent others and the community at large. Mediators persuade the victim to overcome his/her hatred, antagonism, and vengeful desires. In doing so, they say, "If you close your eyes because of the bad people around you, you will not see the good people passing by". In this Africans' proverb, closing the eyes represents refusing to solve the problem through peaceful negotiation.

If disputants refuse to attend a peaceful discussion and utter further provocative words, mediators, for example, in Zimbabwe reprimand them by saying, "If your mouth were a knife, it would cut off your lips". Ethiopian mediators also discourage disputants from speaking too much, saying, "The fool speaks, the wise man listens". Besides, the Cameroonians say, "A chattering bird builds no nest". Moreover, if disputants keep on resisting the mediators' advice, they could be warned by the Africans' proverb, "Ears that do not listen to advice accompany the head when it is chopped off".

When one of the disputants shows resistance to a peaceful settlement of a dispute because he/she and/or his/her group is more powerful than his/her opponent, the Shona people from Zimbabwe warn that "every power is subject to another power". Hence, as is said by the Ethiopians, "What is inflated too much will burst into fragments". If mediators think that disputants are showing resistance because they are being manipulated by other parties, they tell them not to be the tools of others, using proverbs like the following from Botswana, "A fool and water will go the way they are diverted".

When mediators advise a public figure or a head of a certain institution, they give due emphasis to the implications of his/her wrongdoing for other people around him/her. For example, the Urhobo from Nigeria say, "When the roots of a tree begin to decay, it spreads death to the branches" (Esiri urhe de gbo ko orue omen e neje) (Ohwovoriole 2011: 127) (see conflict resolution scenario 1, Nos. 16-17). Here, while the root symbolises a senior person, head, etc., the branches connote subordinates of the senior or head. Moreover, there are instances when the offending elder or leader faces serious criticism using proverbs, for he/she has failed to be a role model for his/her community. In this regard, Yankah (2012: 50) has documented his actual observation of such an occasion as presented below. The proverb (see conflict resolution scenario 2, Nos. 3-4) along with the discourse was spoken, following the failure of a 70-year-old man to utter the Great Oath of the community, presented by a 40-year-old plaintiff 
who accused the defendant of illegally farming his piece of land, for claiming the land.

\section{Conflict resolution scenario 2}

Interaction: judicial proceedings

Size of audience: $\quad 60$ or more

Proverb speaker: man, 60 years of age

Place: $\quad$ Kumasi (palace of the king of Asante)

\section{Original language: Akan}

You, elder X,

1. I remember you were once a sub-chief. By the grace of the ancestors, you were

2. once the Yokohene of -----. You yourself know you are elder; apologies, the

3. elders have said, the forest bird may be pardoned, if it doesn't know that rice is

4. edible grain; but bird of the grassland has no excuse. If one should be ignorant

5. of tradition, it should not be an elder like you. You were once a sub-chief; a land

6. claim has been backed by the Great Oath and you, of all, still encouraged your

7. wife to plough the land; an elder like you, what is your worth if you hold the

8. Great Oath in contempt? You are guilty!

In the proverb, a person who makes a mistake deliberately is symbolised by a bird of grassland, while a person who makes a mistake unknowingly is represented by a forest bird. Hence, the lesson is that a person who makes a mistake deliberately will suffer the consequence.

This being so, traditional African societies give due emphasis to a win-win solution of a dispute. They try to identify the interests of both parties and they work to come up with a solution which fairly satisfies both sides (Ohwovoriole 2011). In their efforts to advance a win-win principle of conflict resolution, the Oromo from Ethiopia say, "For the lake not to dry, for the frogs not to die" (Akka Haroon hin gonne akka raachi hin dune) (GIZ 2013: 22). By the same token, the Igbos from Nigeria say, "Let the kite perch and let the eagle perch also, whichever denies the other its perching right, let its wings break off..." (Egbe bere ugo bere nke si ibe ya ebela nku kwapu ya) (Oraegbunam 2009: 58-59). Here, the lake, frog, kite, and eagle connote disputants. Both proverbs emphasise the necessity for negotiation which leads to a win-win solution.

To this end, disputants are usually urged to compromise some of their positions and focus on give-and-take for the sake of peaceful coexistence. That is why the Tigray say, "For the safety of the clay oven, let the rat pass by" (Menti eta mugogo tihlef eta enchiwa). The aforementioned proverbs are used to advo- 
cate the relevance of considering the demands of others to achieve successful reconciliation that realises peace and harmony. They promote this view for they believe that as the Kenyans say, "There is no cure that does not cost". Compromising someone's demand for the benefit of the other side and the community at large means that both parties, along with the mediators, can negotiate fair agreement that can satisfy both sides as well as the community as a whole.

In fact, if the truth-finding process has found that one person/group is clearly a victim while the other is clearly an offender, compensation may precede apology and forgiveness. Depending on the level of damage, a victim may be compensated by the offender. In this instance, the offending group employ collective compensation; they believe that, as the Ethiopians say, "Fifty lemons are a load for one person, but for fifty persons they are perfume" (Amsa lomi leand sew shekmu leamsasew gin gitu). In this context, the lemon is a metaphor for the offender's burden of paying compensation. The proverb expounds that collective compensation is vital in lightening the burden of an offender while developing a sense of belonging for community members who contribute something to the compensation. This way, they strengthen their group solidarity. Otherwise, if a member of a community fails to share the problem now, all the burden will fall on him/her in case he/she faces a similar problem in the future. To advise community members not to risk this challenge, the Tigray say, "One who eats alone, dies alone" (Beynu ya zibli'es Beynu yimewut). The Zimbabweans also use the same expression in the same context.

The ultimate goal of traditional African societies' conflict resolution process is, however, restoring peace and harmony among the disputing groups in particular and the community as a whole (Olateju 2013). Justice for traditional African communities is apology, forgiving and forgetting and eventually restoring social relations in the interest of peaceful coexistence (Ohwovoriole 2011). Vengeance and malice are not part of their notion of justice (Oraegbunam 2009). In this regard the Yoruba warn that "it is sickness that can be cured, as we cannot cure death" (Àisàn làá wò, a kì í wo ikú) (Adegoju 2009: 63). By this, they mean that plotting murder as revenge causes irremediable fatal damage.

As the Kenyans say, "After a foolish deed comes remorse". Hence, moving towards settling a matter, offender's regret for his/her wrongdoing is conveyed through his/her apology. At this juncture, the Congolese say, "Lower your head modestly while passing, and you will harvest bananas". The Batswana also say, "It is better to walk than curse the road". Both proverbs encourage apology by the offender and forgiveness by the victim. Furthermore, the Yoruba people use the following proverb to underscore the necessity of forgiving, "If we chastise a child with the right hand, we should draw them near ourselves with the left" (Bí a bá fi owó òtún bá omo wí, à sì tún fi owó òsì fà á móra) (Adegoju 2009: 
65). In the proverb, the offender who is begging for forgiveness is symbolised as a child being disciplined. The same people also clearly indicate the appropriateness of forgiving the offender after an admission of guilt and an apology. As they say, "If one agrees that one is guilty in a case, then one will not stay long on his knees" (B'elejo ba m'ejoo re lebi, ko nipe lori ikunle) (Kazeem 2010: 6). The social bonds of traditional African societies cannot be easily broken. For this reason, casting a wrongdoer out of his/her community is hardly possible.

Mediators in traditional African societies always believe that their success in their reconciliation efforts is heavily dependent on the Creator. The Creator supports and monitors their conflict resolution endeavours. For example, the Amhara of Ethiopia in this regard say, "Man begins, the Creator completes it" (Sew yasibal fetari yfetsmal). For this reason, they beg Him to be with them in their reconciliation efforts and give credit to Him at the end of a successful reconciliation (Olateju 2013). Mediators persuade disputants that everything is predetermined by the Creator, as the Urhobo from Nigeria say, "The water to be drunk by one from the river always awaits one" (Ame ra da dje waan) (Ohwovoriole 2011: 130). Remedy for every problem is also from the Creator. The Ghanaians believe that "if God breaks your leg, He will teach you how to limp" (Afriprov 2004: 1). The Tigray also believe that "when God creates cliff, along with it, He creates a ladder" (Gedel ya enkifetirs medeyaybo ewun yfetr). In the proverb, social challenge and its possible solution are symbolised by cliff and ladder respectively.

With the above understanding, verdicts of mediators are respected and enforced through the support of their Creator and the social morality of the target community. In principle, every community member has a responsibility to respect and implement the decisions of the mediators. It is believed that someone who breaks consensus may suffer social sanctions and his/her Creator's coercion (Adan \& Pkalya 2006). That is why the Tanzanians from East Africa say, "If you refuse the elder's advice, you will walk the whole day" (Afriprov 2000: 1).

\section{CONCLUSION}

In an effort made to find out contributions of traditional African societies' proverbs in depicting the communities' conflict prevention and conflict management principles through socio-semiotic approach to discourse studies and interpretive analysis, they are found indispensable in portraying peace-keeping and peacemaking values among the communities. For their discourse to have pragmatic force, taste, and precision, communities widely employ proverbs when they prevent and resolve conflicts using their own conflict prevention and conflict 
management principles. Persuading disputants to avoid conflict and to settle their dispute peacefully, preaching communal moral, teaching lessons of good and evil, and explaining the need for and benefit of mutual understanding and peaceful coexistence are among the social goals performed by employing proverbs. If the communities use culture and context sensitive proverbs, they play a vital role in legitimising traditional African society's conflict prevention and conflict management institutions.

Through their proverbs, traditional African societies preach closing space for dispute, avoiding provocation and settlement of disagreement through peaceful discussion and patience. Despite all these efforts, when disputes occur, the communities employ proverbs which encourage taking communal responsibility to address the dispute, following transparent truth-finding procedures, creating forum for participatory negotiation, finding win-win solutions, and aiming at reconciliation and restoration of communal peace and harmony.

If the proverbs are to continue being a source of wisdom for the generations to come, they have to be properly collected, documented, and used where appropriate. Makamani (2013: 11) argues, "Africans should, and can, utilise their own knowledge systems to overcome challenges hence become truly independent and thus experience a developmental boost guided by Ubuntu/Unhu and/or Ujamaa way of life enshrined in African proverbs". Otherwise, as Dore (n.d.), cited in ECA (2007: 11), notes, "When policy neglects history, culture, and social context, huge amounts of effort and resources can be wasted on poorly conceived initiatives".

\section{NOTES}

1 Except for some of the Ethiopian proverbs, proverbs without source are taken from Special Dictionary, available at: http://www.special-dictionary.com/, last accessed on November 27, 2015.

2 Though priority is given to seniors either in terms of age or social status, any matured person who is accepted by disputants and capable of mediation can be a mediator.

\section{REFERENCES}

Abayomi, Onifade 2014. Philosophical Significance of Yoruba Proverbs. Available at http://www.academia.edu/3397082/Philosophical_Significance_of_Yoruba_ Proverbs, last accessed on November 27, 2015.

Adan, Mohamud \& Pkalya, Ruto 2006. Conflict Management in Kenya: Towards Policy and Strategy Formulation. Practical Action (report). Available at http:// practicalaction.org/media/view/6194, last accessed on November 27, 2015. 
Adegoju, Adeyemi 2009. Rhetoric in Conflict-Related Yoruba Proverbs: Guide to Constructive Conflict Resolution in Africa. African Study Monographs, Vol. 30, No. 2, pp. 55-69. Available at http://www.africa.kyoto-u.ac.jp/asm/normal/asm_302.html, last accessed on November 27, 2015.

Adeyemi, Adeniyi Babadunde \& Salawudeen, Olabisi Muijidat 2014. The Place of Indigenous Proverbs in Peace Education in Nigeria: Implications for Social Studies Curriculum. International Journal of Humanities and Social Science, Vol. 4, No. 2, pp. 186-192. Available at http://www.ijhssnet.com/journals/Vol_4_ No_2_Special_Issue_January_2014/18.pdf, last accessed on November 27, 2015.

Afriprov 2000 = African Proverb of the Month. Afriprov.org: African Proverbs, Sayings and Stories. Available at http://www.afriprov.org/index.php/african-proverb-ofthe-month/26-2000proverbs/152-march2000.html, last accessed on November 27, 2015.

Afriprov 2004 = African Proverb of the Month. Afriprov.org: African Proverbs, Sayings and Stories. Available at http://www.afriprov.org/index.php/african-proverb-ofthe-month/30-2004proverbs/205-sep2004.html, last accessed on November 27, 2015.

Afriprov 2005 = African Proverb of the Month. Afriprov.org: African Proverbs, Sayings and Stories. Available at http://www.afriprov.org/index.php/african-proverbof-the-month/31-2005proverbs/220-patience-can-cook-a-stoneq-fulfulde-beninburkina-faso-cameroon-central-african-republic-chad-mali-niger-nigeria-sudanand-togo-.html, last accessed on November 27, 2015.

Akinmade, Arinola C. 2012. The Decline of Proverbs as a Creative Oral Expression: A Case Study of Proverb Usage among the Ondo in the South-Western Part of Nigeria. AFRREV LALIGENS: An International Journal of Language, Literature and Gender Studies, Vol. 1, No. 2, pp. 127-148. Available at http://afrrevjo.net/ journals/laligens/Vol_1_(2)_art_10.pdf, last accessed on November 27, 2015.

Albert, Isaac Olawale \& Awe, Tinu, \& Hérault, Georges \& Omitoogun, Wuyi 1995. Informal Channels for Conflict Resolution in Ibadan, Nigeria. Ibadan: Institut français de recherche en Afrique.

Ayittey, George B. N. 1991. Indigenous African Institutions. Ardsley-on-Hudson, NY: Transnational Publishers.

Degnew, Tesfaye \& Wodajo, Mesfin 2014. The Socio- Cultural Functions of Kafa Proverbs. African Journal of History and Culture, Vol. 6, No. 6, pp. 94-99. DOI: 10.5897/ AJHC2014.0198.

ECA 2007 = United Nations Economic Commission for Africa. Relevance of African Traditional Institutions of Governance. Available at http://www.uneca.org/search/ node/Relevance\%20of\%20African\%20Traditional\%20Institutions\%20of\%20 Governance, last accessed on December 1, 2015.

Finnegan, Ruth 1970. Oral Literature in Africa. Oxford \& New York: Oxford University Press.

GIZ 2013 = Deutsche Gesellschaft für Internationale Zusammenarbeit. Shimgelina under the Shade: Merging Ethiopian Wise-Counsel Mediation and Facilitative Mediation. A Training Manual. Addis Ababa: Central Printing Press. Available at http://www.ziviler-friedensdienst.org/sites/ziviler-friedensdienst.org/files/anhang/ 
publikation/zfd-merging-ethiopian-wise-counsel-mediation-and-facilitativemediation-1949.pdf, last accessed on November 27, 2015.

Halliday, Michael A. K. \& Hasan, Ruqaiya 1985. Language, Context and Text: Aspects of Language in a Social-Semiotic Perspective. Victoria: Deakin University.

Hussein, Wolyie J. 2009. A Discursive Representation of Women in Sample Proverbs from Ethiopia, Sudan and Kenya. Research in African Literatures, Vol. 40, No. 3, pp. 96-108. http://dx.doi.org/10.2979/RAL.2009.40.3.96.

Kaphagawani, Didier N. 2006 [2004]. African Conceptions of a Person: A Critical Survey. In: K. Wiredu (ed.) A Companion to African Philosophy. Malden, MA: Blackwell, pp. 332-342.

Kazeem, Ademola 2010. The Logic in Yoruba Proverbs. Itupale Online Journal of African Studies, Vol. 2, pp. 1-14. Available at http://www.researchgate. net/publication/259717846_The_Logic_in_Yoruba_Proverbs, last accessed on November 27, 2015.

Kuruk, Paul 2002. African Customary Law and the Protection of Folklore. Copyright Bulletin, Vol. XXXVI, No. 2, pp. 4-32. Available at http://unesdoc.unesco.org/ images/0012/001277/127784e.pdf, last accessed on November 27, 2015.

Makamani, R. 2013. African Proverbs and Conflict Management: A Study of Selected Shona, Oshivambo, Yoruba and Swahili Proverbial Expressions. Available at http://ir.polytechnic.edu.na/bitstream/handle/10628/429/Makamani.\%20African\%20proverbs.pdf;jsessionid=C35036DA2353AA683DC60E0BC12EF03D?se quence=1, last accessed on November 27, 2015.

Malunga, Chiku \& James, Rick 2004. Using African proverbs in organizational capacity building. Praxis Note No. 6. Available at http://www.intrac.org/data/files/ resources/103/Praxis-Note-6-Using-African-Proverbs-in-Organisational-CapacityBuilding.pdf, last accessed on November 27, 2015.

Mandova, Evans \& Wasosa, Wellington 2013. The Role of Proverbs in the Shona Judicial System with Special Reference to Nhango Dzokusuma Nyaya Padare. International Journal of Asian Social Science, Vol. 3, No. 4, pp. 871-877. Available at http://www.aessweb.com/pdf-files/ijass-3(4)-871-877.pdf, last accessed on November 27, 2015.

Moumakwa, Constance 2010. The Botswana Kgotla System: A Mechanism for Traditional Conflict Resolution in Modern Botswana. Case Study of the Kanye Kgotla. Master's Thesis in Philosophy of Peace and Conflict Transformation. Faculty of Humanities, Social Sciences and Education, University of Troms $\emptyset$. Unpublished. Available at munin.uit.no/bitstream/handle/10037/3211/thesis.pdf?sequence=1, last accessed on November 27, 2015.

Nkonya, Ephraim \& Markelova, Helen \& Kato, Edward 2009. Looking beyond the Obvious: Uncovering the Features of Natural Resource Conflicts in Uganda. CAPRi Working Paper No. 95. Available at: www.ifpri.org/sites/default/files/publications/ capriwp95.pdf, last accessed on November 27, 2015.

Obisakin, Lawrence Olufemi 2010. Proverbs in Communication: A Conflict Resolution Perspective. New York: Triumph Publishing.

Ohwovoriole, Felicia 2011. Peacemaking and Proverbs in Urhobo and Yoruba Martial Conflicts: Part 1. African Conflict and Peacebuilding Review, Vol. 1, No. 2, pp. 122-135. Available at https://muse.jhu.edu/journals/african_conflict_and_ peacebuilding_review/toc/acp.1.2.html, last accessed on November 27, 2015. 
Olateju, Animashaun Rofiah 2013. Preserving the Traditional Measures of Preventing Conflict in Africa. Journal of Education Research and Behavioral Sciences, Vol. 12, pp. 232-238. Available at http://www.apexjournal.org/jerbs/archive/2013/Dec/ fulltext/Olateju.pdf, last accessed on November 27, 2015.

Olatunji, Olatunde 1984. Features of Yoruba Oral Poetry. Ibadan: University Press Limited.

Oraegbunam, Ikenga K.E. 2009. The Principles and Practice of Justice in Traditional Igbo Jurisprudence. Available at www.ajol.info/index.php/og/article/viewFile/52335/40960, last accessed on November 27, 2015.

Phillips, Foluso 2011. Peacemaking and Proverbs in Urhobo and Yoruba Martial Conflicts: Part 2. African Conflict \& Peacebuilding Review, Vol. 1, No. 2, pp. 136-152. Available at https://muse.jhu.edu/journals/african_conflict_and_peacebuilding_ review/toc/acp.1.2.html, last accessed on November 27, 2015.

Porter, Terry B. 2005. Identity Subtexts in the Discursive Construction of Sustainability. Available at http://www.mngt.waikato.ac.nz/ejrot/Vol9_1/Porter.pdf, last accessed on November 27, 2015.

Renkema, Jan 2004. Introduction to Discourse Studies. Amsterdam: John Benjamins Publishing.

Special Dictionary. Proverbs. Available at http://www.special-dictionary.com/proverbs/, last accessed on November 27, 2015.

UN 2004 = United Nations Security Council. The Rule of Law and Transitional Justice in Conflict and Post-Conflict Societies: Report of the Secretary-General, S / 2004 / 616, 23 August. Available at www.unrol.org/files/2004\%20report.pdf, last accessed on November 28, 2015.

Wojkowska, Ewa 2006. Doing Justice: How Informal Justice Systems Can Contribute. United Nations Development Programme, Oslo Governance Centre. Available at http://siteresources.worldbank.org/INTLAWJUSTINST/Resources/EwaWojkowska. pdf, last accessed on November 28, 2015.

Yankah, Kwesi 2012 [1985]. The Proverb in the Context of Akan Rhetoric. New York: Diasporic Africa Press.

Yitah, Helen 2006. Throwing Stones in Jest: Kasena Women's "Proverbial" Revolt. Oral Tradition, Vol. 21, No. 2, pp. 233-249. Available at http://journal.oraltradition. org/issues/21ii/yitah, last accessed on November 28, 2015. 